\title{
KONFLIK BATAS WILAYAH DI ERA OTONOMI MENURUT UNDANG-UNDANG 32 TAHUN 2004
}

\author{
Mashuri, MA \\ Dosen Fakultas Ekonomi dan Ilmu Sosial \\ Universitas Islam Negeri Sultan Syarif Kasim Riau
}

\begin{abstract}
Abstrak
Mengkaji konflik batas wilayah pada era Otonomi Daerah yang mana pada kajian ini lebih mendalam akan mengkaji tentang konflik yang terjadi berkaitan dengan tapal batas, hal ini disebabkan oleh lahirnya undang-undang Otonomi daerah akhirnya menjadi persoalan mengenai tapal batas antar kabupaten dan juga antar provinsi yang ada diIndonesia.

Kerja sama antar daerah perbatasan merupakan salah satu tema penting untuk memberikan solusi atas munculnya konflik-konflik sumber daya alam (SDA) dan konflik kewenangan lainya. Walaupun belum banyak ditemukan kajian-kajian mengenai kerja sama antar daerah tersebut, akan tetapi perlu diciptakan pembagian kewenangan antar pusatprovinsi dan juga kabupten kota di Indonesia. Oleh karna itu nuansa penyeragaman kebijakan pusat terhadap heterogenitas daerah yang banyak menimbulkan konflik ti tingkat local. Masalah tersebut muncul karna adanya bebrapa kelemahan dari undang-undang Otonomi daerah Nomor 22 ahun 1999 tentang pemerintahan daerh(yang undang-undang tersebut tidak berlaku lagi sejak diundangkannya undang-undang No. 32 tahun 2004). Konflik ini terjadi dikarenakan oleh beberapa hal diantaranya adalah lemahnya koordinasi dalam penyelenggaraan fungsi pemerintahan diantara tingkat pemerintahan baik pusat, Provinsi dan juga kabupaten/kota. Disisi lain juga disebabkan oleh pengelolaaan sumber daya alam, daerah merasa lebih berhak dn memiliki wewenang sendiri. Konflik bata wilayah ini bisa dielesaikan apabila pemerintah local dan pusat berperan penting an tidak mengedepankan kepentingn elit politik.
\end{abstract}

Kata Kunci : Batas Wilayah, Konflik, Otonomi Daerah

\section{PENDAHULUAN}

Pemberlakuan Otonomi Daerah berdasarkan Undang-undang No. 22 Tahun 1999 kemudian direvisi menjadi Undangundang No. 32 Tahun 2004 tentang Pemerintahan Daerah dan Undang-undang No. 33 tahun 2004 tentang Perimbangan Keuangan Daerah antara Pemerintah Pusat dan Daerah, memberikan implikasi kepada daerah untuk secara proaktif mengembangkan berbagai rencana dan kebijakan pembangunan daerahnya. Otonomi Daerah ini mendorong pertumbuhan kemandirian daerah dengan pendekatan perencanaan dari bawah (bottom up planning) yang mengakomodasikan berbagai aspirasi yang tumbuh dan berkembang di daerah, dalam kerangka Negara Kesatuan Republik Indonesia (NKRI).

Penyesuaian kewenangan dan fungsi penyediaan pelayanan antar Pemerintah Pusat, Propinsi dan Kabupaten/Kota sudah memuat tujuan politis, maupun teknis. Secara politis, desentralisasi kewenangan pada masing-masing daerah menjadi perwujudan dari suatu tuntutan reformasi seperti 
direfleksikap, dalam Garis-garis Besar Haluan Negara. Secara teknis masih terdapat sejumlah besar persiapan yang harus dilakukan untuk menjamin penyesuaian kewenangan dan fungsi-fungsi tersebut secara efektif.

Secara umum, beberapa prinsip dasar yang harus dipegang oleh semua pihak dalam pelaksanaan Otonomi Daerah menurut Undang-undang Nomor 32 Tahun 2004 ini paling tidak adalah; pertama, otonomi daerah harus dilaksanakan dalam konteks Negara kesatuan; kedua, pelaksanaan Otonomi Daerah menggunakan tata cara desentralistis, dengan demikian peran (daerah sangat menentukan; ketiga, pelaksanaan Otonomi Daerah harus dimulai dengan mendefenisikan kewenangan, organisasi, personal kemudian diikuti dengan keuangan, bukan sebaliknya; keempat, perimbangan keuangan yang dimaksud adalah perimbangan horizontal/ antar Daerah, Provinsi dan Kabupaten/Kota, di samping itu perimbangan vertikal, antar pusat dan daerah; kelima, fungsi pemerintah Pusat masih sangat vital, baik dalam kewenangan strategic (moneter, pertahanan, luar negeri, dan hukum), maupun untuk mengatasi ketimpangan antar Daerah (Kaloh, 2002: 47).

Perkembangan politik lokal yang berimbas dari Otonomi Daerah saat sekarang ini membuat daerah yang menunjukkan jati dirinya sehingga kadang kala terjadi konflik dari otonomi, sehingga dalam kajian politik lokal ini membuat kajian terfokus pada masalah yang mengkrucut pada persoalan konflik politik masyarakat lokal, khususnya konflik tapal batas sebuah wilayah.

Dalam pelaksanaan Otonomi Daerah, perlu selalu dikembangkan hubungan yang serasi antara Pemerintahan Pusat dan Daerah serta antar Daerah dan antar kelompok masyarakat dalam lintas agama dan budaya guna mempererat dan menumbuhkan semangat kesatuan. Hal ini mengingat dalam peranan otonomi saat ini kebebasan dapat memicu fanatisme kedaerahan yang hanya berorientasi pada primordialisme yang sempit. Disamping itu perlu dilakukan identifikasi dan penyamaan visi dan persepsi dalam penanganan hal-hal yang menunjukkan sumber kerawanan konflik seperti berikut ini:

1. Eksploitasi Sumber Daya Alam (SDA) yang berada di perbatasan antar Provinsi, Kabupaten/ Kota.

2. Disparitas (perbedaan) antara satu daerah dengan daerah lainnya.

3. Egoisme "keangkuhan" dari masingmasing daerah yang tidak menyadari eksistensinya diantara daerah lainnya.

4. Disparitas antar etnis, antar wilayah, antar tingkat pendidikan, tingkat sosial, dan tingkat budaya.

5. Bentuk dan jenis pelayanan masyarakat yang dipengaruhi secara ketat oleh

batas wilayah sehingga membingungkan masyarakat (Kaloh; 99).

Guna menghindari hal-hal yang akan terjadi dalam penerapan undangundang Nomor 32 Tahun 2004 tentang Pemerintahan Daerah salah satunya adalah sengketa tapal batas daerah ketika terjadi pemekaran sesuai dengan undang-undang Otonomi Daerah, maka diperlukan kedewasaan yang baik dan koordinasi yang berkesinambungan antara pusat dengan daerah dan antara daerah dengan masyarakat. Dalam rangka kebijakan dan penegasan batas daerah Provinsi, Kabupaten/Kota, atau wilayah sengketa sekitar Kabupaten/Kota yang terjadi, sebagai implementasi undang-undang Nomor 32 Tahun 2004 tentang Pemerintahan Daerah, dan karena itu dipandang perlu mengambil langkah-langkah guna mengantisipasi terjadinya permasalahan dan konflik tapal batas, yang selalu cenderung menimbulkan dampak negatif terhadap pembangunan daerah dan pemerataan pertumbuhan. Permasalahan tapal batas inilah yang kadang kala menimbulkan konflik dan sengketa antar daerah. Dalam ruang lingkup tapal batas daerah itulah harus dilaksanakan 
penyelenggaraan kewenangan masing-masing daerah, artinya kewenangan suatu daerah pada dasarnya tidak boleh diselenggarakan melampaui batas daerah yang telah ditetapkan dalam peraturan perundangundangan (Direktur Perbatasan Depdagri, 2002; 2).

Konflik yang berkembang saat ini di Indonesia adalah konflik vertikal dan konflik horizontal. Konflik vertikal terjadi antara rakyat dan pemerintah, sedangkan konflik horizontal sering terjadi karena unsur politisnya sangat kental sekali dan rentan dengan konflik. Konflik horizontal yang berkaitan dengan tapal batas ini adalah konflik horizontal yang bersifat politis ekonomis, atau gabungan dari kedua unsur itu, yaitu konflik antar kelompok masyarakat.

Konflik horizontal merupakan ekor atau efek ikutan dari konflik-konflik yang telah terjadi sebelumnya. Oleh karenanya secara obyektif telah muncul konflik dalam masyarakat, maka pihak yang bertikai dapat mengundang simpati atau solidaritas sosial, sehingga konflik merembet pada akar rumput. Pada kasus ini timbulnya konflik horizontal umumnya disebabkan karena terjadi nya perselisihan paham dalam hal yang sepele, seperti konflik tapal batas ini yang hanya memperebutkan bagaimana pengurusannya secara administratif dalam sebuah pemerintahan, serta penggunaan dan pembagian atas wilayah.

Sejak implementasi Otonomi Daerah yang luas, nyata dan bertanggung jawab berdasarkan Undang-Undang Nomor 22 Tahun 1999 tentang Pemerintahan Daerah yang kemudian diganti Undang-Undang Nomor 32 tahun 2004, batas antar daerah menjadi hal yang sangat penting menjadi perhatian daerah. Arti penting batas daerah berkaitan dengan batas kewenangan daerah yang kemudian berimplikasi pada kewenangan pengelolaan sumber-sumber daya di daerah.

Konflik antar daerah di Indonesia sering terjadi berkaitan dengan penetapan batas antar daerah. Salah satu kasus konflik adalah antagonisme yang terjadi dalam penegasan batas wilayah antara Kecamatan dan juga antar kabupaten di seluruh Indonesia. Faktor penyebabnya berdimensi banyak serta saling berkaitan faktor yang satu dengan yang lainnya. Faktor tersebut meliputi: faktor-faktor yang bersifat struktural, faktor kepentingan, hubungan antar manusia dan konflik data, yang semuanya dapat dikategorikan menjadi faktor Tatar belakang, faktor pemicu konflik dan faktor akselelator. Konflik yang terjadi menyebabkan belum terwujudnya batas yang jelas dan pasti antara kedua daerah tersebut baik secara administatif maupun fisik, yang selanjutnya berakibat pada timbulnya "dampak konflik" berupa terjadi nya dualisme kewenangan pemberian data yuridis atas tanah-tanah tertentu pada sebagian proses pengurusan. bukti kepemilikan hak atas tanah (sertifikat) khususnya di tingkat desa /kelurahan yang batas wilayahnya tidak tegas.

Di samping itu adanya ketidakpastian kewenangan dalam pelayanan Ijin Mendirikan Bangunan (IMB). Rekomendasi untuk penyelesaian konflik yaitu dilakukan melalui konsiliasi dengan mediasi oleh tingkat pemerintah lebih atas (Pemerintah Kabupaten, Gubernur dan jika perlu Menteri Dalam Negeri) dengan didahului pihak berkonflik mengupayakan de-eskalasi konflik, dan terakhir didukung upaya slit politik yang dilandasi semangat persatuan dan kesatuan dalam kerangka NKRI.

Munculnya konflik atau benturan kepentingan antar daerah, pada dasarnya merupakan refleksi dari kesalahpahaman, kegamangan, dan egoisme daerah dalam

melaksanakan otonomi. Otonomi sering dipersepsikan lebih dari sekedar dapat mengatur rumah tangganya sendiri, namun hingga tidak mau dicampuri oleh pihak lain walaupun dalam konteks koordinasi dan 
sinkronisasi. Peningkatan daya saing daerah yang diamanatkan Undang-undang lebih dipersepsikan secara negatif, sehingga daerah enggan menjalin sinkronisasi regional (antardaerah).

Di samping itu, Kabupaten/kota sering meremahkan otonomi ini sebagai kewenangan untuk menggali pendapatan daerah yang sebanyak-banyaknya melalui pajak dan retribusi serta eksploitasi sumber daya dan dengan mengabaikan kepentingan jangka panjang dan generasi mendatang. Pruitt dan Rubin menjelaskan bahwa konflik terjadi ketika tidak terlihat adanya alternatif yang dapat mernuaskan aspirasi kedua belah pihak dan lebih jauh masing-masing pihak memiliki alasan untuk percaya bahwa mereka mampu mendapatkan sebuah objek bernilai untuk diri mereka sendiri atau mereka percaya bahwa mereka berhak memiliki obyek tersebut. Mengacu pada penjelasan Pruit dan Rubin tersebut, dapat diasumsikan ada obyek bernilai yang dianggap berhak dimiliki oleh masing-masing pihak. Rumusan obyek bernilai ini membantu untuk mengidentifikasi-bagian wilayah yang disengketakan sebagai obyek bernilai (Pruit dan Rubin,2004).

Konflik geografis ini pada umumnya terjadi karena adanya perbedaan kepentingan. Konflik yang terjadi di Kabupaten dan Provinsi adalah konflik yang sudah lama terjadi. Hal tersebut terkait dengan kepemilikan hak tanah ulayat yang ada disuatu daerah dan juga berbagai kepentingan yang lain, Masalah inilah yang melatar belakangi konflik ini terjadi sehingga konflik yang berkepanjangan ini tak kunjung terselesaikan oleh instansi terkait bahkan teradang membiarkan., pemerintah dan pihak yang berkepentingan yang diharapkan menyelesaikan permasalahan ini.

Jadi dengan melihat beberapa kejadian setelah munculnya undang-undang otonomi daerah terkadang hal tersebut menambah permasalahan,sebagai usaha pemecahan persolan tersebut maka dalam memenuhi kebutuhan ruang untuk kegiatan pemerintah dan pelayanan terhadap masyarakat, dipandang perlu dan sudah saatnya dilakukan pengkajian lebih mendalam terhadap konflik yang terjadi dari kasus tapal batas ini karna berkaitan dengan undang-undang Otonomi daerah.

\section{KERANGKA TEORITIK}

Telah disebutkan pada sebelumnya bahwa konflik dalam penegasan batas wilayah antara Kecamatan, Kabupaten dan juga Provinsi selalu terjadi yang berkaitan dengan tema konflik mengenai batas wilayah, ini dapat dikatakan bahwa kasus ini merupakan salah satu kasus dari sejumlah kasus konflik mengenai batas daerah yang terjadi di daerah-daerah lain akibat masih terdapatnya kekurangan dari undang-undang tersebut.

Hal tersebut ditunjukkan dengan banyaknya konflik mengenai batas wilayah yang terjadi setelah lahirnya undangundang Otonomi Daerah. Oleh karna itu berkaitan dengan konflik tersebut yang beberapa di antaranya berakhir dengan saling mengakui SDA yng ada diperbatasan daerah tersebut. Dalam memahami permasalahan konflik batas wilayah perlu secara lebih mendalam dan terarah dilakukan pengwasan dan juga perubahan.

Istilah otonomi daerah dan desentralisasi dalam konteks bahasan sistem penyelenggaraan pemerintahan sering digunakan secara campur aduk (interchangeably). Kedua istilah tersebut secara akademik bisa dibedakan, namun secara praktis dalam penyelenggaraan pemerintahan tidak dapat dipisahkan. Karena itu tidak mungkin masalah Otonomi Daerah dibahas tanpa mempersandingkannya dengan konsep desentralisasi. Bahkan menurut banyak kalangan Otonomi Daerah adalah desentralisasi itu sendiri. 
Adapun visi penting dari Otonomi Daerah itu dapat dirumuskan dalam tiga ruang lingkup interaksinya yang utama : Politik, Ekonomi, Sosial dan Budaya (Syaukani, 2002). Dibidang politik, karena otonomi adalah buah dari kebijakan desentralisasi dan demokratis, maka ia harus dipahami sebagai sebuah proses untuk membuka ruang bagi lahirnya kepala pemerintahan daerah yang dipilih secara demokratis, memungkinkan berlangsungnya penyelenggaraan pemerintah yang merespon terhadap kepentingan masyarakat luas dan memilihara suatu mekanisme pengambilan keputusan yang tact pada asas pertanggung jawaban publik. Demokratisasi pemerintahan juga berarti adanya transpsransi kebijakan. Artinya untuk setiap kebijakan yang diambil harus jelas siapa yang memprakarsai kebijakan itu, apa tujuannya, berapa ongkos yang harus dipikul, siapa yang diuntungkan, apa resiko yang harus ditanggung, dan siapa yang harus bertanggungjawab jika kebijakan itu gagal. Otonomi Daerah juga berarti kesempatan membangun struktur pemerintahan yang sesuai dengan kebutuhan daerah, membangun sistem dan pola karir politik dan administrasi yang kompetitif, serta mengembangkan sistem manajemen pemerintahan yang efektif.

Di bidang ekonomi, otonomi daerah disatu pihak harus menjamin lancarnya pelaksanaan kebijakan ekonomi nasional di daerah, dan dipihak lain terbukanya peluang bagi pemerintah daerah mengembangkan kebijakan regional dan lokal untuk mengoptimalkan pendayagunaan potensi ekonomi di daerahnya. Dalam konteks ini, Otonomi Daerah akan memungkinkan lahirnya berbagai prakarsa pemerintah daerah untuk menawarkan fasilitas investasi, memudahkan proses perizinan usaha, dan membangun berbagai infrastruktur yang menunjang perputaran ekonomi di daerah. Dengan demikian, otonomi daerah akan membawa masyarakat ketingkat kesejahteraan yang lebih tinggi dari waktu ke waktu.

Di bidang sosial dan budaya otonomi daerah harus dikelola sebaik mungkin demi menciptakan dan memilihara harmoni sosial, dan pada saat yang sama, memilihara nilainilai lokal yang dipandang kondusif dalam menciptakan kemampuan masyarakat untuk merespon dinamika kehidupan disekitarnya (Tim ICCE UIN Jakarta: 2003).

Otonomi Daerah adalah kewenangan daerah otonomi untuk mengatur dan mengurus kepentingan masyarakat menurut prakarsa sendiri berdasarkan aspirasi masyarakat, sesuai dengan peraturan perundang-undangan.

Pemerintah daerah dengan otonomi adalah proses peralihan dari sistem dekonsentrasi ke sistem desentralisasi. Otonomi adalah penyerahan urusan Pemerintah Pusat kepada Pemerintah Daerah yang bersifat operasional dalam rangka sistem birokrasi pemerintah. Tujuan Otonomi Daerah adalah mencapai efisiensi dan efektifitas dalam pelayanan kepada masyarakat.

Tujuan yang hendak dicapai dalam penyerahan urusan ini adalah antara lain; menumbuhkembangkan daerah dalam berbagai bidang, meningkatkan pelayanan kepada masyarakat, menumbuhkan kemandirian daerah dan meningkat daya saing daerah dalam proses pertumbuhan.

Sejalan dengan penyerahan urusan, apabila urusan tersebut akan menjadi beban daerah, maka akan dilaksanakan melalui asas "Medebewind" atau asas pembantuan. Proses dari dentralisasi ke desentralisasi ini pada dasarnya tidak semata-mata desentralisasi administratif, tetapi juga bidang politik dan sosial budaya.

Dengan demikian dampak pemberian otonomi ini tidak hanya terjadi pada organisasi/administrasi lembaga pemerintah daerah saja, akan tetapi berlaku juga pada masyarakat (public), badan atau lembaga 
swasta dalam berbagai bidang (HAW. Widjaja, 2000: 76-77).

Negara Kesatuan Republik Indonesia dalam penyelenggaraan pemerintahannya menganut asas desentralisasi, dekonsentrasi dan tugas pembantuan. Prinsip penyelenggaraan desentralisasi adalah otonomi seluasluasnya dalam arti daerah diberikan kewenangan mengatur dan mengurus semua urusan pemerintahan di luar yang menjadi urusan pemerintah. Daerah memiliki kewenangan membuat kebijakan daerah untuk memberikan pelayanan, peningkatan peranserta, prakarsa dan pemberdayaan masyarakat yang bertujuan pada peningkatan kesejahteraan rakyat.

\section{DAFTAR PUSTAKA}

Kaloh, J., Mencari Bentuk Otonomi Daerah, Rineka Cipta, Jakarta, 2002

Kaho, Josef Riwu., Prospek Otonomi Daerah di Negara Republik, Idetifikasi beberapa Faktor yang mempengaruhi Penyelenggaraannya, Rajawali, Jakarta, 1991

HAW. Widjaja., Otonomi Daerah dan Daerah Otonoami, Ed. I Cet. I, Jakarta: PT Raja Garfindo Persada, 2002

Ryias Rasyid, Otonomi Daerah, Jakarta PT Raja Grapindo, 2002

TIM ICCE UIN, Jakarta, 2002

Undang-Undang Nomor 22 Tahun 1999, Tentang Pemerintah Daerah, Sinar Grafika, Jakarta

Undang-undang Nomor 32 Tahun 2004, Tentang Pemerintah Daerah, Sinar Grafika, Jakarta 